\title{
PEMBUATAN BIHUN DARI TEPUNG SORGUM TERMODIFIKASI MENGGUNAKAN LACTOBACILLUS BULGARICUS
}

\author{
Kristinah Haryani $^{1)}$,Galuh Salindri ${ }^{2)}$, Jansonchia ${ }^{3)}$ dan Suryanto ${ }^{4)}$ \\ ${ }^{1,2,3)}$ Departemen Teknik Kimia, Fakultas Teknik, Universitas Diponegoro \\ J1. Prof. Soedarto, SH, Kampus Undip Tembalang, Semarang, Indonesia 50275 \\ 4) Jurusan Teknik Mesin .Politeknik Negeri Semarang \\ J1. Prof. Soedarto, SH, Semarang, Indonesia 50275 \\ Email: krisyani_83@yahoo.co.id
}

\begin{abstract}
Abstrak
Sorgum dapat menjadi salah satu alternatif sumber pangan, salah satunya dengan mengolah sorgum menjadi bihun. Bihun sorgum dibuat dari tepung sorgum yang telah difermentasi oleh bakteri asam laktat (BAL) Lactobacillus bulgaricus, juga dengan penambahan tepung maizena pada pembuatan bihun sorgum-maizena diharapkan dapat meningkatkan tekstur dari bihun tersebut. Penelitian ini terdiri fermentasi tepung sorgum dan pembuatan bihun. Dari hasil fermentasi tepung sorgum, terdapat peningkatan kadar protein dan penurunan kadar karbohidrat, lemak, dan abu. Hasil analisa bihun sorgum menunjukkan tiap varian komposisinya mengalami peningkatan nilai daya serap air; penurunan nilai cooking loss; dan penurunan waktu rehidrasi. Dari hasil tersebut ditentukanlah formulasi terpilih bihun sorgum yakni pada komposisi 100\% tepung sorgum tergelatinisasi.Selanjutnya dibuatlah bihun sorgum-maizena, dimana tiap varian komposisinya mengalami peningkatan nilai daya serap air; penurunan nilai cooking loss; penurunan waktu rehidrasi; dan penurunan nilai hardness.Saran pada penelitian ini hendaknya terdapat pengontrolan suhu yang lebih akurat agar produk yang dihasilkan lebih baik.
\end{abstract}

Kata Kunci : "bihun”, “fermentasi”, "sorgum”, “maizena”.

\section{Pendahuluan}

Kebutuhan pangan masyarakat Indonesia sampai saat ini masih bergantung pada komoditas tertentu, seperti beras dan gandum. Padahal Indonesia masih memiliki sumber pangan utama lain (non-beras), salah satunya adalah sorgum.Di Indonesia sorgum merupakan tanaman sereal pangan ketiga setelah padi dan jagung.Komposisi nutrisi dasar sorgum secara umum relatif tidak berbeda dengan serealia lainnya seperti jagung, beras, dan gandum, yakni terdiri dari karbohidrat, protein, lemak, vitamin, dan mineral.(Suarni dan Firmansyah, 2013). Namun, dalam pemanfaatan sorgum, masih banyak kendala yang menghadang, diantaranya teksturtepung sorgum yang tidak sesuai dengan prevalensi organoleptik orang Indonesia, karena tepung sorgum mengandung tanin yang berasa pahit dan kelat. Selain itu, tanin dikategorikan sebagai antinutrisi yang biasa terdapat pada tanaman leguminoceae, secara ilmiah dapat berikatan dengan protein, karbohidrat, dan mineral yang mengakibatkan menurunnya daya cerna nutrisi (Elefatio et al. dalam Suarni dan Firmansyah, 2013).
Salah satu cara untuk mengembangkan sorgum adalah dengan mengubahnya menjadi produk yang dapat diterima masyarakat, seperti pembuatan bihun dari tepung sorgum.Untuk meningkatkan kualitas dari tepung sorgum sehingga dapat dijadikan sebagai bahan baku pembuatan bihun, maka dikembangkanlah tepung sorgum termodifikasi, dengan cara fermentasi menggunakan bakteri asam laktat (BAL) dari genus Lactobacillus.Selain itu juga terdapat penambahan tepung maizena untuk pembuatan bihun sorgum-maizena untuk meningkatkan tekstur bihun. Tujuan penelitian ini adalah mengkaji pembuatan bihun sorgum dalam berbagai varian perbandingan komposisi tepung sorgum termodifikasi yang digelatinasi dengan tepung sorgum termodifikasi yang tak digelatinasi; mengkaji pembuatan bihun sorgum-maizena dalam berbagai varian perbandingan komposisi tepung sorgum termodifikasi yang digelatinasi (formulasi terpilih) dengan penambahan tepung maizena; dan menganalisa karakteristik bihun secara fisik dan kimia. 


\section{Bahan dan Metode}

Bahan baku yang digunakan dalam pembuatan bihun sorgum dan bihun sorgummaizena adalah tepung sorgum, starter basah Lactobacillus bulgaricus yang diperoleh dari Sleman dengan spesifikasi jumlah bakteri menggunakan metode (Total Plate Count) TPC adalah $1,8 \times 10^{5} \mathrm{CFU} / \mathrm{ml}$, tepung maizena, aquadest, dan garam.

\subsection{Pembuatan Tepung Sorgum Terfermentasi}

Tepung sorgum difermentasikan dengan cara melarutkan tepung sorgum dalam aquadest steril dengan rasio tepung sorgum : aquadest adalah $1: 1,25$. Setelah itu dilakukan penginokulasian bakteri Lactobacillus bulgaricus sebanyak 2\% dari jumlah bahan baku. Campuran lalu ditutup dengan alumunium foil dan difermentasi selama 24 jam pada suhu $37^{\circ} \mathrm{C}$. Setelah difermentasi, tepung sorgum dipindahkan ke dalam loyang kemudian dikeringkan dengan oven pada suhu $50^{\circ} \mathrm{C}$.

\subsection{Pembuatan Bihun Sorgum}

Tepung sorgum terfermentasi yang telah diperoleh kemudian dibagi menjadi dua bagian, salah satu bagian tepung disisihkan terlebih dahulu untuk proses yang lain, sedangkan bagian tepung lainnya dicampurkan dengan aquadest dan garam. Setelah dicampurkan, campuran digelatinisasi pada suhu $71-80^{\circ} \mathrm{C}$ selama kurang lebih 15 menit. Setelah terbentuk menjadi gel, tepung sorgum yang tergelatinisasi ditambahkan dengan tepung sorgum yang tak tergelatinisasi untuk diuleni sebelum dicetak dalam variasi variabel. Adonan yang terbentuk lalu dicetak hingga menjadi untaian-untaian tipis, lalu dikeringkan menggunakan dry oven pada suhu $50^{\circ} \mathrm{C}$ selama 6 jam sehingga diperoleh bihun kering.

Formulasi dalam pembuatan bihun adalah sebagai berikut.

\section{Tabel 1. Formula pembuatan bihun sorgum dalam berbagai komposisi}

\begin{tabular}{cccccc}
\hline \multirow{2}{*}{ Bahan } & $\mathbf{5}$ Jumlah (\%) \\
\cline { 2 - 6 } & $\mathbf{1 0 0 \%}$ & $\mathbf{8 0 \%}$ & $\mathbf{6 0 \%}$ & $\mathbf{4 0 \%}$ & $\mathbf{2 0 \%}$ \\
\hline $\begin{array}{c}\text { Tepung sorgum } \\
\text { terfermentasi }\end{array}$ & 100 & 100 & 100 & 100 & 100 \\
\hline Garam & 2 & 2 & 2 & 2 & 2 \\
\hline Aquadest & 400 & 400 & 400 & 400 & 400 \\
\hline $\begin{array}{c}\text { Tepung sorgum } \\
\text { tergelatinisasi }\end{array}$ & 100 & 80 & 60 & 40 & 20 \\
\hline Tepung maizena & $\begin{array}{c}\text { Pada formulasi bihun sorgum yang terpilih akan } \\
\text { dicampurkan dengan tepung maizena dengan } \\
\text { varian komposisi penambahan 10\%; 20\%; dan } \\
\text { 30\% tepung maizena }\end{array}$ \\
\hline
\end{tabular}

\subsection{Analisa Kimia}

Analisa kimia yang dilakukan meliputi analisa kadar abu, kadar karbohidrat, kadar protein, dan kadar lemak. Analisis tersebut dilakukan pada tepung sorgum yang sebelum dan sesudah fermentasi.

\subsection{Analisa Fisik}

Analisa fisik yang dilakukan pada bihun sorgum dan bihun sorgum-maizena meliputi analisa daya serap air, waktu rehidrasi, cooking loss, dan hardness

\section{Hasil dan Pembahasan}

\subsection{Karakteristik Tepung Sorgum}

Proses pembuatan bihun pada penelitian ini menggunakan bahan baku berupa tepung sorgum yang telah difermentasi.Tepung sorgum awal (sebelum difermentasi) ini dianalisis komposisi kimianya melalui analisis proksimat yang terdiri dari kadar protein, karbohidrat, lemak, dan abu.

Tabel 2.Hasil analisis proksimat tepung sorgum sebelum fermentasi

\begin{tabular}{|c|c|c|c|c|}
\hline Komposisi & Protein & Karbohidrat & Lemak & Abu \\
\hline Besarnya (\%w) & 7,517 & 78,484 & 1,36 & 1,23 \\
\hline
\end{tabular}

Tepung sorgum yang telah diperoleh tadi lalu dicampurkan dengan air (fermentasi semi padat) dan diinokulasikan bakteri asam laktat Lactobacillus bulgaricus, lalu difermentasi selama 24 jam pada suhu $37^{\circ}$ C.Setelah difermentasi, tepung sorgum dikeringkan sehingga dapat digunakan untuk pembuatan bihun.Berikut hasil analisis proksimat tepung sorgum terfermentasi. 
Tabel 3. Hasil analisis proksimat tepung sorgum sesudah fermentasi

\begin{tabular}{|c|c|c|c|c|}
\hline Komposisi & Protein & Karbohidrat & Lemak & Abu \\
\hline $\begin{array}{c}\text { Besarnya } \\
(\% \mathbf{w})\end{array}$ & 8,229 & 75,408 & 0,76 & 1,06 \\
\hline
\end{tabular}

Tepung sorgum yang telah difermentasi mengalami kenaikan kandungan protein, hal ini disebabkan karena selama fermentasi bakteri asam laktat Lactobacillus bulgaricus menghasilkan enzim proteinase. Adanya kenaikan kadar protein diperoleh dari aktivitas enzim proteinase yang dihasilkan oleh mikroba yang ada dalam proses fermentasi. Selain itu, mikroorganisme pada saat fementasi juga dapat menghasilkan protein yang disebut Single cell protein (SCP) (Tandrianto dkk., 2014). Hal ini yang menyebabkan kadar protein meningkat setelah fermentasi.

Sedangkan kadar lemak yang mengalami penurunan pada tepung sorgum terfermentasi karena lemak yang ada pada tepung digunakan sebagai sumber energi bagi mikroorganisme untuk melakukan fermentasi (Ginandjar, 1977 dalam Kurniati, 2012).

Penurunan kadar karbohidrat selama proses fermentasi disebabkan karena karbohidat digunakan untuk memenuhi kebutuhan energi untuk pertumbuhan mikroorganisme (Ardhana, 1982 dalam Kurniati, 2012). Bahan organik diuraikan oleh mikroorganisme disebabkan oleh enzim amilase dan lipase yang bekerja dalam pemecahan amilum dan lemak dari substrat sehingga kandungan bahan organik selama fermentasi mengalami penurunan (Ginandjar, 1977 dalam Kurniati, 2012).

\subsection{Bihun Sorgum}

Terdapat 5 komposisi dalam pembuatan bihun sorgum, yakni komposisi pertama bihun yang terbuat dari $20 \%$ tepung sorgum tergelatinisasi dengan $80 \%$ tepung sorgum tak tergelatinisasi; komposisi kedua bihun yang terbuat dari $40 \%$ tepung sorgum tergelatinisasi dengan $60 \%$ tepung sorgum tak tergelatinisasi; komposisi ketiga bihun yang terbuat dari $60 \%$ tepung sorgum tergelatinisasi dengan $40 \%$ tepung sorgum tak tergelatinisasi; komposisi keempat bihun yang terbuat dari $80 \%$ tepung sorgum tergelatinisasi dengan $20 \%$ tepung sorgum tak tergelatinisasi; dan komposisi kelima bihun yang terbuat dari $100 \%$ tepung sorgum tergelatinisasi.

\subsection{Daya Serap AirBihun Sorgum}

Daya serap air (DSA) menunjukkan kemampuan bihun untuk menyerap air secara maksimal selama proses pemasakan.

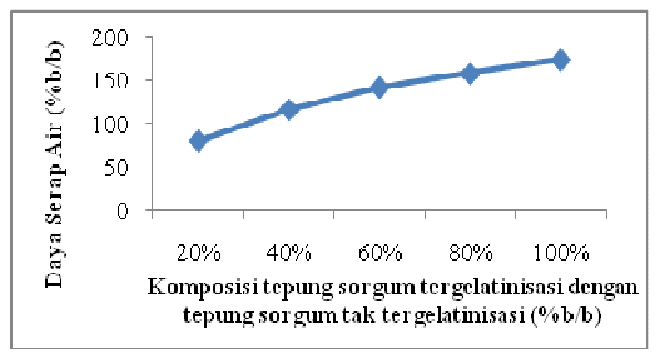

\section{Gambar 1. Daya serap air bihun sorgum pada berbagai komposisi}

Pada penelitian ini, tepung sorgum digelatinisasi pada suhu berkisar $71-80^{\circ} \mathrm{C}$, sesuai dengan suhu gelatinisasi tepung sorgum (Turhan \& Sagol, 2004). Dari gambar 1 dapat diketahui pada komposisi $20 \%$ tepung sorgum tergelatinisasi memiliki nilai daya serap air sebesar $80 \%$; pada komposisi $40 \%$ tepung sorgum tergelatinisasi memiliki nilai daya serap air sebesar $116 \%$; pada komposisi $60 \%$ tepung sorgum tergelatinisasi memiliki nilai daya serap air sebesar $142 \%$; pada komposisi $80 \%$ tepung sorgum tergelatinisasi memiliki nilai daya serap air sebesar 158\%; dan pada komposisi $100 \%$ tepung sorgum tergelatinisasi memiliki nilai daya serap air sebesar $174 \%$.

Dapat dilihat pada grafik bahwa terdapat peningkatan nilai daya serap air yang dipengaruhi oleh banyaknya jumlah tepung sorgum yang tergelatinisasi.Hal ini dikarenakan molekul pati mempunyai gugus hidrofilik yang dapat menyerap air.Bagian yang amorf dapat menyerap air dingin sampai dengan 30\%.Pemanasan pati dapat meningkatkan daya serap air sampai $60 \%$ (Winarno, 1992).Penyerapan air yang besar disebabkan karena pecahnya ikatan hidrogen pada bagian yang amorf. 
Selain itu, pada saat tepung tergelatinisasi, pati yang ada dalam tepung akan terhidrolisis karena panas. Ketika pati terhidrolisis, makromolekulnya akan terdegradasi menjadi molekul-molekul yang lebih kecil dengan rantai yang lebih pendek. Setelah pati terhidrolisis maka pati akan lebih mudah mengalami depolimerisasi. Depolimerisasi ditandai dengan adanya putusnya ikatan rantai utama sehingga menyebabkan pemendekan panjang rantai dan penurunan bobot molekul.Dengan adanya penurunan bobot molekul pati tersebut, secara tidak langsung maka ukuran molekul pati menjadi lebih kecil.Kecilnya ukuran molekul pati memudahkan air untuk masuk ke dalam molekul pati sehingga daya serap air meningkat (Marwan, 2006).

Oleh karena itu, semakin banyak tepung sorgum yang tergelatinisasi maka nilai daya serap airnya akan meningkat, karena semakin banyak pati yang terpecah akibat proses gelatinisasi. Dengan demikian pada komposisi $100 \%$ tepung sorgum tergelatinisasi memiliki nilai daya serap air terbesar diantara komposisi yang lain.

\subsection{Kehilangan Pemasakan Sorgum \\ Padatan \\ Akibat (Cooking Loss)Bihun}

Kehilangan padatan akibat pemasakan (KPAP)/cooking loss terjadi karena lepasnya sebagian kecil pati dari untaian bihun saat pemasakan.

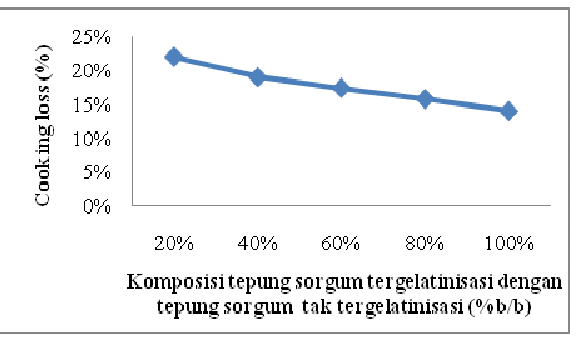

\section{Gambar 2. Cooking loss bihun sorgum pada berbagai komposisi}

Pada penelitian ini, tepung sorgum digelatinisasi pada suhu berkisar $71-80^{\circ} \mathrm{C}$, sesuai dengan suhu gelatinisasi tepung sorgum (Turhan \& Sagol, 2004). Dari gambar 4.2 dapat diketahui pada komposisi $20 \%$ tepung sorgum tergelatinisasi memiliki nilai cooking loss sebesar 22\%; pada komposisi $40 \%$ tepung sorgum tergelatinisasi memiliki nilai cooking loss sebesar 19\%; pada komposisi $60 \%$ tepung sorgum tergelatinisasi memiliki nilai cooking loss sebesar $17,4 \%$; pada komposisi $80 \%$ tepung sorgum tergelatinisasi memiliki nilai cooking loss sebesar 15,8\%; dan pada komposisi $100 \%$ tepung sorgum tergelatinisasi memiliki nilai cooking loss sebesar $14 \%$.

Dapat dilihat pada grafik bahwa terdapat penurunan nilai cooking loss yang dipengaruhi oleh banyaknya jumlah tepung sorgum yang tergelatinisasi.Kandungan amilosa yang cukup tinggi merupakan suatu hal yang diharapkan dalam pembuatan bihun karena memiliki daya ikat yang lebih kuat, sehingga nilai cooking loss rendah.

Menurut teori, pada saat tepung digelatinisasi, energi panas menyebabkan ikatan hidrogen pati menjadi melemah. Ikatan yang lemah memudahkan air masuk ke dalam granula dan memungkinkan sedikit melarutnya dan terjadi pertukaran molekul amilosa menuju ke air, sehingga kadar amilosa menurun (Palupi dkk., 2017).

Sehingga, pada penelitian ini kurang sesuai teori, yakni cooking loss tertinggi pada komposisi $100 \%$ tepung tergelatinisasi, padahal seharusnya kadar amilosa yang tertinggi berada pada komposisi $20 \%$ dikarenakan jumlah tepung yang digelatinisasi lebih sedikit dibanding komposisi lain sehingga pati yang terhidrolisis pun semakin sedikit dan menyebabkan kadar amilosa dari tepung yang disubstitusi (tepung sorgum yang tidak tergelatinisasi) masih tinggi.

\subsection{Waktu Rehidrasi Bihun Sorgum}

Waktu rehidrasi merupakan waktu yang diperlukan bihun kering untuk menjadi basah kembali setelah perebusan.

Tabel 4. Waktu rehidrasi bihun sorgum pada berbagai komposisi

\begin{tabular}{cc}
\hline Komposisi bihun sorgum & Waktu rehidrasi (menit) \\
\hline $20 \%$ tepung tergelatinisasi & 02.52 \\
$40 \%$ tepung tergelatinisasi & 04.54 \\
$60 \%$ tepung tergelatinisasi & 05.03 \\
$80 \%$ tepung tergelatinisasi & 05.48 \\
$100 \%$ tepung tergelatinisasi & 06.26 \\
\hline
\end{tabular}


Dari tabel diatas dapat diketahui pada komposisi 20\%; 40\%; 60\%; 80\%; dan 100\% tepung sorgum tergelatinisasi memiliki nilai waktu rehidrasi yang cukup berbeda, dan menunjukkan adanya peningkatan waktu rehidrasi di setiap komposisinya.

Perbedaan waktu rehidrasi tersebut dikarenakan adanya perbedaan kadar amilosa yang ada pada tiap komposisi. Kadar amilosa berpengaruh pada waktu rehidrasi, dimana semakin tinggi kadar amilosa semakin cepat waktu rehidrasinya. Kadar amilosa yang ada pada tiap komposisi dipengaruhi oleh gelatinisasi.Hal ini dikarenakan pada saat tepung tergelatinisasi, energi panas menyebabkan ikatan hidrogen pati menjadi melemah. Ikatan yang lemah memudahkan air masuk ke dalam granula dan memungkinkan sedikit melarutnya dan terjadi pertukaran molekul amilosa menuju ke air (Palupi dkk., 2017). Sehingga kadar amilosa yang ada pada komposisi pun semakin berkurang.

Maka pada penelitian ini kadar amilosa tertinggi ada pada komposisi 20\% tepung sorgum tergelatinisasi, dimana jumlah tepung yang digelatinisasi lebih sedikit dibanding komposisi lain sehingga pati yang terhidrolisis pun semakin sedikit dan menyebabkan kadar amilosanya masih tinggi. Oleh karena itu, waktu rehidrasi pada komposisi $20 \%$ tepung sorgum tergelatinisasi lebih singkat dibanding komposisi yang lain.

\subsection{Formula Terpilih Adonan Bihun Sorgum}

Dari komposisi 20\%; 40\%; 60\%; 80\%; dan $100 \%$ tepung sorgum tergelatinisasi menunjukkan bahwa pada komposisi $100 \%$ tepung sorgum tergelatinisasi memiliki nilai cooking loss yang terbaik karena lebih rendah dibandingkan cooking loss pada komposisi lain. Oleh karena itu, komposisi $100 \%$ tepung sorgum tergelatinisasi ditetapkan sebagai formulasi terpilih untuk ditambahkan dengan tepung maizena sebagai bahan baku dalam pembuatan bihun sorgummaizena.

\subsection{Bihun Sorgum-Maizena}

Bihun sorgum-maizena dibuat dari campuran tepung sorgum yang telah digelatinisasi dan tepung maizena. Pada pembuatan bihun sorgum-maizena telah ditetapkan tepung sorgum yang digunakan adalah komposisi $100 \%$ tepung sorgum tergelatinisasi, dimana pada komposisi tersebut nilai cookingloss adalah yang terendah dibanding pada komposisi lain. Untuk pembuatan bihun sorgum-maizena, dibuat pada berbagai perbandingan komposisi penambahan tepung maizena. Terdapat 3 komposisi, yaitu komposisi pertama bihun yang terbuat dari $100 \%$ tepung sorgum tergelatinisasi dengan penambahan $10 \%$ tepung maizena; komposisi kedua bihun yang terbuat dari $100 \%$ tepung sorgum tergelatinisasi dengan penambahan $20 \%$ tepung maizena; dan komposisi ketiga bihun yang terbuat dari $100 \%$ tepung sorgum tergelatinisasi dengan penambahan $30 \%$ tepung maizena

\subsection{Daya Serap Air Bihun Sorgum- Maizena}

Berikut hasil analisa daya serap air pada berbagai komposisi.

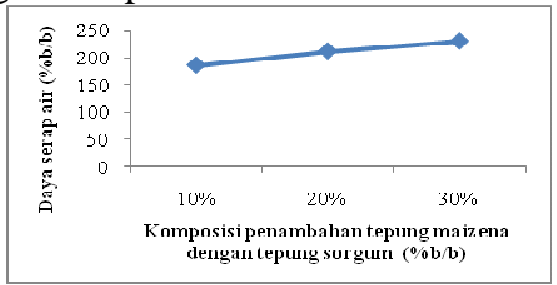

\section{Gambar 3. Daya serap air bihun sorgum- maizena pada berbagai komposisi}

Tepung sorgum tergelatinisasi dicampur dengan tepung maizena dan bersama-sama digelatinisasi pada suhu berkisar $71-80^{\circ} \mathrm{C}$. Dari gambar 3 dapat diketahui pada komposisi penambahan $10 \%$ tepung maizena memiliki nilai daya serap air sebesar $186 \%$; pada komposisi penambahan $20 \%$ tepung maizena memiliki nilai daya serap air sebesar $212 \%$; dan pada komposisi penambahan $30 \%$ tepung maizena memiliki nilai daya serap air sebesar $230 \%$.

Dapat dilihat pada grafik bahwa terdapat peningkatan nilai daya serap air yang dipengaruhi oleh banyaknya jumlah tepung 
maizena yang ditambahkan.Hal ini dikarenakan molekul pati mempunyai gugus hidrofilik yang dapat menyerap air.Bagian yang amorf dapat menyerap air dingin sampai dengan 30\%.Pemanasan pati dapat meningkatkan daya serap air sampai $60 \%$ (Winarno, 1992).Penyerapan air yang besar disebabkan karena pecahnya ikatan hidrogen pada bagian yang amorf.

Selain itu, pada saat tepung tergelatinisasi, pati yang ada dalam tepung akan terhidrolisis karena panas. Ketika pati terhidrolisis, makromolekulnya akan terdegradasi menjadi molekul-molekul yang lebih kecil dengan rantai yang lebih pendek. Setelah pati terhidrolisis maka pati akan lebih mudah mengalami depolimerisasi. Depolimerisasi ditandai dengan adanya putusnya ikatan rantai utama sehingga menyebabkan pemendekan panjang rantai dan penurunan bobot molekul.Dengan adanya penurunan bobot molekul pati tersebut, secara tidak langsung maka ukuran molekul pati menjadi lebih kecil.Kecilnya ukuran molekul pati memudahkan air untuk masuk ke dalam molekul pati sehingga daya serap air meningkat (Marwan, 2006).

Oleh karena itu, semakin banyak tepung maizena yang ditambahkan maka nilai daya serap airnya akan meningkat, karena semakin banyak pati yang terpecah akibat proses gelatinisasi. Dengan demikian pada komposisi penambahan 30\% tepung maizena memiliki nilai daya serap air terbesar diantara komposisi yang lain.

\subsection{Kehilangan Padatan Akibat Pemasakan (Cooking Loss)Bihun Sorgum-Maizena}

Berikut hasil analisa cooking loss pada berbagai komposisi.

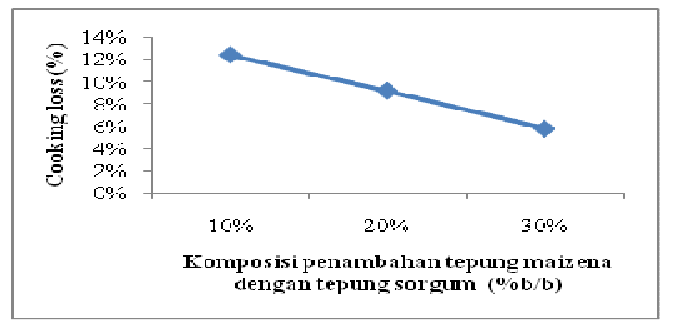

Gambar 4.Cooking loss bihun sorgummaizena pada berbagai komposisi
Dari gambar 4 dapat diketahui pada komposisi penambahan $10 \%$ tepung maizena memiliki nilai cooking loss sebesar 12,4\%; pada komposisi penambahan $20 \%$ tepung maizena memiliki nilai cooking loss sebesar 9,2\%; dan pada komposisi penambahan $30 \%$ tepung maizena memiliki nilai cooking loss sebesar $5,8 \%$.

Dapat dilihat pada grafik bahwa terdapat penurunan nilai cooking loss yang dipengaruhi oleh banyaknya jumlah tepung sorgum yang tergelatinisasi.Kandungan amilosa yang cukup tinggi merupakan suatu hal yang diharapkan dalam pembuatan bihun karena memiliki daya ikat yang lebih kuat, sehingga nilai cooking loss rendah.

Menurut teori, pada saat tepung digelatinisasi, energi panas menyebabkan ikatan hidrogen pati menjadi melemah. Ikatan yang lemah memudahkan air masuk ke dalam granula dan memungkinkan sedikit melarutnya dan terjadi pertukaran molekul amilosa menuju ke air, sehingga kadar amilosa menurun (Palupi dkk., 2017).

Sehingga, pada penelitian ini komposisi penambahan $30 \%$ tepung maizena memiliki penambahan amilosa dari tepung maizena yang lebih tinggi daripada penambahan $10 \%$ tepung maizena dan penambahan $20 \%$ tepung maizena. Maka, pada komposisi penambahan $30 \%$ tepung maizena memiliki nilai cooking loss yang paling rendah.

\subsection{Waktu RehidrasiBihun Sorgum- Maizena}

Berikut hasil analisa waktu rehidrasi pada berbagai komposisi.

\section{Tabel 5. Waktu rehidrasi bihun sorgum-} maizena pada berbagai komposisi

\begin{tabular}{cc}
\hline $\begin{array}{c}\text { Komposisi bihun sorgum- } \\
\text { maizena }\end{array}$ & $\begin{array}{c}\text { Waktu rehidrasi } \\
\text { (menit) }\end{array}$ \\
\hline Penambahan 10\% tepung maizena & 08.51 \\
Penambahan 20\% tepung maizena & 07.42 \\
Penambahan 30\% tepung maizena & 06.41 \\
\hline
\end{tabular}

Dari tabel diatas dapat diketahui pada komposisi penambahan 10\%; $20 \%$; dan $30 \%$ tepung maizena memiliki nilai waktu rehidrasi yang cukup berbeda, dan menunjukkan adanya penurunan waktu rehidrasi di setiap komposisinya. 
Perbedaan waktu rehidrasi tersebut dikarenakan adanya perbedaan kadar amilosa yang ada pada tiap komposisi. Kadar amilosa berpengaruh pada waktu rehidrasi, dimana semakin tinggi kadar amilosa semakin cepat waktu rehidrasinya. Kadar amilosa yang ada pada tiap komposisi dipengaruhi oleh gelatinisasi.Hal ini dikarenakan pada saat campuran tepung digelatinisasi, energi panas menyebabkan ikatan hidrogen pati menjadi melemah. Ikatan yang lemah memudahkan air masuk ke dalam granula dan memungkinkan sedikit melarutnya dan terjadi pertukaran molekul amilosa menuju ke air (Palupi dkk., 2017). Sehingga kadar amilosa yang ada pada komposisi pun semakin berkurang.

Sehingga, pada penelitian ini komposisi penambahan $30 \%$ tepung maizena memiliki penambahan amilosa dari tepung maizena yang lebih tinggi daripada penambahan $10 \%$ tepung maizena dan penambahan 20\% tepung maizena. Maka, pada komposisi penambahan $30 \%$ tepung maizena memiliki waktu rehidrasi yang lebih singkat dibanding komposisi lain.

\subsection{HardnessBihun Sorgum-Maizena}

Berikut hasil analisa hardnessbihun sorgummaizena pada berbagai komposisi.

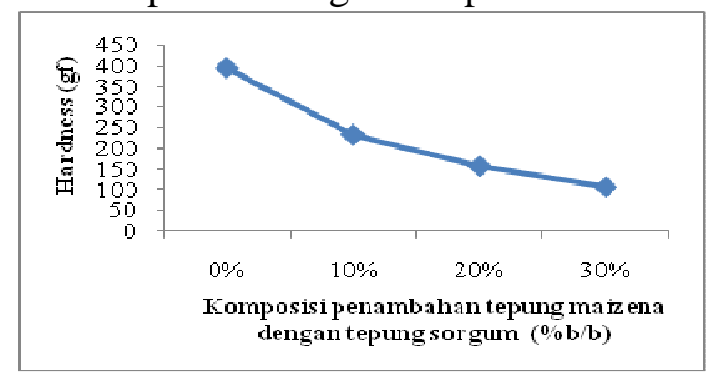

\section{Gambar 5. Hardness bihun sorgum-maizena pada berbagai komposisi}

Dari gambar 4.5 dapat diketahui bahwa pada komposisi penambahan $0 \%$ tepung maizena (bihun komposisi 100\% tepung sorgum tergelatinisasi) mempunyai nilai hardness sebesar 393,975 gf; pada komposisi penambahan $10 \%$ tepung maizena mempunyai nilai hardness sebesar 231,953 gf; pada komposisi penambahan $20 \%$ tepung maizena mempunyai nilai hardness sebesar
155,918 gf; dan pada komposisi penambahan $30 \%$ tepung maizena mempunyai nilai hardness sebesar 105,186 gf.

Dapat dilihat pada grafik bahwa terdapat penurunan nilai hardness dikarenakan adanya perbedaan kadar amilosa yang ada pada tiap komposisi. Kadar amilosa yang ada pada tiap komposisi dipengaruhi oleh gelatinisasi.Hal ini dikarenakan pada saat tepung tergelatinisasi, energi panas menyebabkan ikatan hidrogen pati menjadi melemah. Ikatan yang lemah memudahkan air masuk ke dalam granula dan memungkinkan sedikit melarutnya dan terjadi pertukaran molekul amilosa menuju ke air (Palupi dkk., 2017). Sehingga kadar amilosa yang ada pada komposisi pun semakin berkurang. Berdasarkan kadar amilosa, semakin tinggi kadar amilosa kekerasan dan elastisitas beras semakin rendah.

Sehingga, pada penelitian ini komposisi penambahan $30 \%$ tepung maizena memiliki penambahan amilosa dari tepung maizena yang lebih tinggi daripada penambahan $0 \%$ tepung maizena; penambahan $10 \%$ tepung maizena; dan penambahan $20 \%$ tepung maizena. Maka, pada komposisi penambahan $30 \%$ tepung maizena memiliki nilai hardness yang terendah.

\section{Kesimpulan}

Tepung sorgum dapat digunakan sebagai bahan baku pembuatan bihun dengan cara difermentasi menggunakan Lactobacillus bulgaricus terlebih dahulu. Dari hasil fermentasi terdapat peningkatan kadar protein serta penurunan kadar karbohidrat dan kadar lemak. Tepung sorgum yang telah difermentasi lalu diolah menjadi bihun sorgum dengan varian komposisi 20\%; 40\%; $60 \%$; $80 \%$; dan $100 \%$ tepung sorgum tergelatinisasi.

Bihun sorgum di tiap varian komposisinya mengalami peningkatan nilai daya serap air; penurunan nilai cooking loss; dan penurunan waktu rehidrasi. Dari hasil tersebut ditentukanlah formulasi terpilih bihun sorgum 
yakni pada komposisi $100 \%$ tepung sorgum tergelatinisasi.

Dikarenakan penampilan dari bihun sorgum kurang menarik, maka tepung sorgum disubstitusi oleh tepung maizena untuk pembuatan bihun sorgum-maizena, dengan varian komposisi $100 \%$ tepung sorgum tergelatinisasi dicampur varian komposisi penambahan 10\%; 20\%; dan 30\% tepung maizena, dengan hasil bihun sorgum-maizena yang terbaik ada pada komposisi penambahan $30 \%$ tepung maizena. Bihun sorgum-maizena di tiap varian komposisinya mengalami peningkatan nilai daya serap air; penurunan nilai cooking loss; penurunan waktu rehidrasi; dan penurunan nilai hardness.

\section{UcapanTerimakasih}

Ucapan terimakasih disampaikan kepada Bapak Dr. Siswo Sumardiono, S.T., M.T. selaku Ketua Departemen Teknik Kimia Universitas Diponegoro, Ibu Ir. Kristinah Haryani, M.T. selaku dosen pembimbing penelitian,dan pihak-pihak yang telah membantu baik secara langsung maupun tidak langsung.

\section{Daftar Pustaka}

- Kurniati, T. H., Sunny, F., dan Hatmanti A. (2012). Isolasi dan Karakterisasi Bakteri Penghasil Senyawa Antibakteri yang Berasosiasi dengan Karang Batu dari Perairan Bitung dan Spons dari Selat Makassar. Jakarta: Universitas Negeri Jakarta.

- Marwan, W. S. (2006). Produksi Hidrolisat Pati dan Serat Pangandari Singkong melalui Hidrolisis denganA-Amilase dan Asam Klorida. Bogor: Fakultas Teknologi Pertanian Institut Pertanian Bogor.
- Palupi, H., Zainul A, A., dan Nugroho, M. (2017). Pengaruh Pre Gelatinisasi terhadap Karakteristik Tepung Singkong. Teknologi Pangan : Media Informasi Dan Komunikasi Ilmiah Teknologi Pertanian, 1 (1). Retrieved from http://jurnal.yudharta.ac.id/v2/index. php/TeknologiPangan/article/view/474

- Suarni, dan Firmansyah, I. (2013). Struktur, Komposisi Nutrisi dan Teknologi Pengolahan Sorgum.Sorgum, Inovasi Teknologi dan pengembangan , 260-279.

- Tandrianto, J., Mintoko, D. K., dan Gunawam, S. (2014). Pengaruh Fermentasi pada Pembuatan Mocaf (Modified Cassava Flour) dengan Menggunakan Lactobacillus plantarum terhadap Kandungan Protein.JurnalTeknikPomits, 3(2), pp.143-145.

- Turhan, M., dan Sagol, S. (2004). Abrupt Changes in The Rates of Processes Occurring during Hydrothermal Treatment of Whole Starchy Foods Around The Gelatinization Temperature-A review of the literature. Journal of Food Engineering,62(4),365-371. doi: 10.1016/S0260-8774(03)00252-8

- Winarno, F. G. (1992). Kimia Pangan dan Gizi. Gramedia Pustaka Utama. Jakarta. 